\title{
Rancang Bangun Sistem Kontrol Suhu Dan Ketinggian Air Untuk Pemijahan Ikan Dengan Menggunakan Logika Fuzzy
}

\author{
Steven Bandong ${ }^{1}$, Hesky Stevy Kolibu ${ }^{2}$, Verna Albert Suoth ${ }^{3}$ \\ ${ }^{1}$ Program Studi Fisika, FMIPA, UNSRAT Manado, bandong.steven@gmail.com \\ ${ }^{2}$ Program Studi Fisika, FMIPA, UNSRAT Manado, heskystevy@yahoo.com \\ ${ }^{3}$ Program Studi Fisika, FMIPA, UNSRAT Manado, vernasuoth@yahoo.co.id
}

\begin{abstract}
Abstrak
Pemijahan ikan memerlukan kondisi Lingkungan tertentu untuk dapat terjadi pemijahan yang maksimal. Jika keadaan lingkungan ini tidak terpenuhi maka pemijahan ikan mungkin tidak akan terjadi. Salah satu kondisi lingkungan yang mesti terpenuhi adalah suhu dan ketinggian air. Dalam penelitian diggunakan program fuzzy untuk mengontrol suhu dan ketinggian air. Program fuzzy diunggah ke mikrokontroler Atmega32. Kipas angin dan pemanas air digunakan sebagai aktuator pengontrolan suhu dan pompa air untuk aktuator pengontrolan tinggi air. Media yang dikontrol suhu dan ketinggian airnya adalah sebuah akuarium dengan ukuran $100 \mathrm{~cm}$ x $50 \mathrm{~cm}$ x $40 \mathrm{~cm}$. Penelitian ini berhasil membuat program fuzzy untuk mengontrol suhu dan tinggi air. Sistem kontrol suhu dan tinggi air juga berhasil dirancang dan dibuat. Sistem kontrol dapat mengontrol suhu pada suhu rata-rata $26,0{ }^{\circ} \mathrm{C}$ dari suhu awal $25,4{ }^{\circ} \mathrm{C}$ dengan nilai NRMSE 0,008 . Waktu yang diperlukan untuk mecapai set point adalah 31 menit. Ketinggian air juga berhasil dibuat stabil pada 29,8 $\mathrm{cm}$ dari ketinggian awal air adalah 25,5 cm dengan nilai NRMSE sebesar 0,009. Waktu yang diperlukan untuk mencapai set point adalah 4,5 menit.
\end{abstract}

Kata Kunci: Ketinggian air, Kontrol Suhu, Logika fuzzy, Pemijahan ikan

\section{Design and Construct of the Temperature and Water Levels Controller for Spawning Fish by Using the Fuzzy Logic Control}

\begin{abstract}
Spawning fish requires certain Environmental conditions in order to occurred a maximum spawning. If the environmental condition is not fulfilled, probably, the spawning will be not transpired. One of the environmental conditions that have to settle is temperature and water level. This research used fuzzy program for controlling the temperature and the level of water. Fuzzy program was uploaded to the microcontroller ATmega32. Fans and heaters were used as actuator for controlling the temperature and the water pumps for actuator of high level water controller. The media for controlling the temperature and the height of the water is a $100 \mathrm{~cm} \times 50 \mathrm{~cm} \times 40 \mathrm{~cm}$ aquarium. This research was successfully creating a fuzzy program to control high temperatues and water. The system can control the average temperature of $26.0^{\circ} \mathrm{C}$ from $25.4^{\circ} \mathrm{C}$ with 0.008 NRMSE. It required 31 minutes to reach the set point. The water level was also successfully made stable at $29.8 \mathrm{~cm}$ from the $25.5 \mathrm{~cm}$ initial height of the water with 0.009 NRMSE. It require 4,5 minutes to reach the set point.
\end{abstract}

Keywords: Level of water, Temperature control, Fuzzy logic, Spawning fish

\section{Pendahuluan}

Sistem kontrol (control system) merupakan suatu kumpulan cara atau metode yang dipelajari dari kebiasaan-kebiasaan manusia dalam bekerja, dimana manusia membutuhkan suatu pengamatan kualitas dari apa yang telah mereka kerjakan sehingga memiliki karakteristik sesuai dengan yang diharapkan pada mulanya. Sistem kontrol proses terdiri atas sekumpulan piranti-piranti dan peralatan peralatan elektronik yang mampu menangani kestabilan, akurasi, dan mengeliminasi 
transisi status yang berbahaya dalam proses produksi[1]. Dengan banyaknya dinamika yang terjadi dalam suatu sistem, sistem kontrol menjadi solusi yang handal untuk menjaga kestabilan sistem.

Salah satu hal yang membutuhkan kestabilan sistem adalah pengembangbiakan ikan, khususnya pemijahan ikan. Keberhasilan suatu pemijahan ikan sangat tergantung dari kondisi lingkungan disekitarnya, seperti suhu dan ketinggian air. Jika kondisi lingkungan tidak stabil, besar kemungkinan perkawinan ikan akan mengalami kegagalan atau anak yang dihasilkan cacat [2]. Tentunya hal ini dapat menyebabkan kerugian bagi peternak ikan.

Selama beberapa tahun terakhir kontrol fuzzy telah muncul sebagai alternatif praktis untuk skema pengontrolan otomatis. Logika fuzzy adalah suatu cara tepat untuk memetakan suatu ruang input ke dalam suatu ruang output. Teknik ini menggunakan teori matematis himpunan fuzzy. Logika fuzzy berhubungan dengan ketidakpastian yang telah menjadi sifat alamiah manusia [3]. Dengan kata lain, Kontrol fuzzy memiliki keunggulan dalam menangani dinamika yang tidak pasti ini karena menyediakan kemampuan penalaran manusia. Karenanya penulis terdorong untuk menerapkannya dalam rancang bangun sistem pengontrolan suhu dan tinggi air pada akuarium.

Pemijahan ikan memerlukan pengontrolan terhadap suhu dan ketinggian air agar ikan dapat memijah dengan maksimal. Sehingga yang menjadi masalahnya, bagaimana mengontrol suhu dan ketinggian air untuk pemijahan ikan dengan menggunakan kontrol logika fuzzy? Namun dalam perancangan dan pembuatan sistem pengontrolan suhu dan ketinggian air ini dibatasi hanya dengan menggunakan kontrol logika fuzzy dan masih dalam skala laboratorium. Penelitian ini bertujuan untuk membuat program fuzzy pengontrolan suhu dan ketinggian air dan merancang serta membuat sistem pengontrolan suhu dan ketinggian air.

\section{Sistem Kontrol}

Sistem kontrol adalah sekumpulan komponen yang bekerja sama di bawah pengarahan suatu kecerdasan mesin. Sasaran sistem kontrol adalah untuk mengatur keluaran (output) dalam suatu keadaan yang telah ditetapkan oleh masukan (input) melalui komponen sistem kontrol.

\section{Kontroler}

Kontroler (controller) adalah suatu alat atau cara untuk modifikasi sehingga karakteristik sistem dinamik (dynamic system) yang dihasilkan sesuai dengan yang kita kehendaki.

\subsection{Logika Fuzzy}

Logika fuzzy merupakan sebuah logika yang memiliki nilai kekaburan dan kesamaran (fuzzynes) antara benar dan salah. Dalam teori logika fuzzy sebuah nilai bisa bernilai benar dan salah secara bersamaan namun berapa besar kebenaran dan kesalahan suatu nilai tergantung kepada derajat keanggotaan yang dimilikinya.

Langkah pertama dalam memproses logika fuzzy mengandung transformasi domain yang dinamakan fuzzifikasi. Masukan crisp ditransformasikan ke dalam masukkan fuzzy. Langkah kedua disebut basis aturan. Basis aturan berisi aturan-aturan fuzzy yang digunakan untuk pengendalian sistem. Aturan-aturan ini dibuat berdasarkan logika dan intuisi manusia, serta berkaitan erat dengan jalan pikiran dan pengalaman pribadi yang membuatnya. Langkah selanjutnya adalah evaluasi aturan. Berdasarkan basis aturan yang telah dibuat, variabel-variabel masukan fuzzy diolah lebih lanjut untuk mendapatkan suatu penyelesaian. Dengan demikian dapat diambil suatu keputusan berupa variabel fuzzy keluaran. Hasil ini harus diubah kembali menjadi varibel numerik non fuzzy melalui proses defuzzifikasi.

\subsection{Mikrokontroler}

Mikrokontroler adalah sebuah chip yang berfungsi sebagai pengontrol rangkaian elektronik dan umumnya dapat menyimpan program didalamnya. Mikrokontroler AVR memiliki arsitektur Havard, yaitu memisahkan memori untuk kode program dan memori data [4]. ATmega32 tergolong mikrokontroler jenis AVR yang memiliki arsitektur RICS (Reduced Instruction Set) 8 bit [5]. Jenis Mikrokontroler ini dapat digunakan untuk mengolah data per bit ataupun 8 bit secara bersamaan. 


\subsection{ADC (Analog to Digital Converter)}

ADC adalah sebutan untuk rangkaian pengubah input sinyal analog (sinyal kontinu terhadap waktu) menjadi output sinyal digital (sinyal diskret atau terkuantisasi terhadap waktu). Sinyal digital yang dihasilkan ADC berupa bilangan basis 2 (hanya terdiri dari angka 0 dan 1). Persamaan untuk pengubahan sinyal analog ke digital adalah :

$$
N=V_{\text {in }} \frac{2^{n}-1}{V_{f s}}
$$

Keterangan :

$$
\begin{array}{llll}
N & =\text { Data dalam biner (bit) } & n & =\text { Jumlah bit ADC }(\text { bit }) \\
V_{\text {in }} & =\text { Tegangan masuk ke ADC }(\mathrm{mV}) & V_{f s} & =\text { Tegangan pada skala penuh }(\mathrm{mV})
\end{array}
$$

\section{Sensor}

\subsection{Sensor Suhu}

Sensor suhu yang digunakan dalam penelitian ini adalah sensor LM 35. Sensor suhu LM35 berfungsi untuk mengubah besaran fisis yang berupa suhu menjadi besaran elektrik tegangan. Sensor ini memiliki parameter bahwa setiap kenaikan $1{ }^{\circ} \mathrm{C}$ tegangan keluarannya naik sebesar $10 \mathrm{mV}$ dengan batas maksimal keluaran sensor adalah $1,5 \mathrm{~V}$ pada suhu $150{ }^{\circ} \mathrm{C}[6]$.

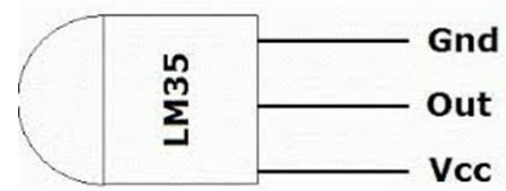

Gambar 1. IC Sensor LM 35

\subsection{Sensor Level Air}

Sensor level air yang digunakan dalam penelitian ini adalah sensor ultrasonik HCSR04 seperti yang terlihat pada Gambar 2. Sensor ini menghasilkan gelombang suara pada frekuensi tinggi yang kemudian dipancarkan oleh pin trigger. Pantulan gelombang suara (echo) yang mengenai benda di depannya akan ditangkap oleh pin echo. Jarak benda yang ada di depan modul sensor tersebut didapatkan dengan cara mengetahui lama waktu antara dipancarkannya gelombang suara oleh transmitter sampai ditangkap kembali oleh receiver [7].

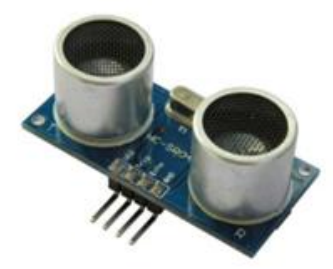

Gambar 2. Sensor Ultrasonik PING

\section{Aktuator}

Aktuator (actuator) adalah elemen yang mengonversikan besaran listrik analog menjadi besaran lainnya misalnya kecepatan putaran dan merupakan perangkat elektromagnetik yang menghasilkan daya gerakan sehingga dapat menghasilkan gerakan pada robot.

\section{Plant}

Plant (Plant) adalah sesuatu obyek fisik yang dikontrol. Obyek fisik yang akan dikontrol dalam penelitian ini adalah suhu dan ketinggian air.

\subsection{Suhu}

Suhu didefinisikan sebagai ukuran atau derajat panas dinginnya suatu benda atau sistem. Pada hakikatnya suhu adalah ukuran energi kinetik rata-rata yang dimiliki oleh atom-atom suatu benda. Dengan kata lain suhu menggambarkan bagaimana gerakan atom-atom penyusun benda. Termometer adalah alat yang digunakan untuk mengukur suhu sebuah benda [8]. 


\subsection{Ketinggian Air}

Ketinggian air dalam sistem dipengaruhi oleh besarnya debit air yang masuk dan juga debit air yang ditarik keluar. Debit air adalah besarnya volume air yang mengalir per satuan waktu melalui suatu pipa dengan luas penampang A dan kecepatan v.

$$
Q=\frac{V}{t} \text { atau } Q=A \cdot v
$$

Keterangan :

$Q=$ Debit air

$V=$ Volume air

$\left(\mathrm{m}^{3} / \mathrm{s}\right)$

$v=$ Kecepatan alir fluida

$t=$ waktu

$(\mathrm{m} / \mathrm{s})$

$A=$ Luas penampang tabung alir $\left(\mathrm{m}^{2}\right)$

(s)

\subsection{Pemijahan Ikan}

Keberhasilan suatu perkawinan pada ikan sangat tergantung pada kondisi lingkungan disekitarnya. Jika kondisi lingkungannya kurang menunjang, besar kemungkinan perkawinan tersebut akan gagal, misalnya suhu dan ketinggian air [2]. Perubahan suhu sebesar $5{ }^{\circ} \mathrm{C}$ di atas normal dapat menyebabkan stres pada ikan bahkan kerusakan jaringan dan kematian [9] Pada ikan maskoki beberapa kondisi lingkungan di bawah ini harus terpenuhi agar ikan dapat memijah optimal :

1. Wadah pemijahan berpasangan atau massal berupa akuarium berukuran $100 \mathrm{~cm} \times 50 \mathrm{~cm} \times$ $40 \mathrm{~cm}$ dengan tinggi air $30 \mathrm{~cm}$.

2. Air harus steril dan jernih, $\mathrm{pH} 6-7$, serta suhu $22^{\circ} \mathrm{C}-26^{\circ} \mathrm{C}[10]$.

\section{Metode Penelitian}

\subsection{Waktu dan tempat}

Penelitian ini dilaksanakan di Laboratorium Instrumentasi Fisika Fakultas MIPA UNSRAT. Penelitian berlangsung selama bulan Juni 2014 - Mei 2015.

\subsection{Alat}

Alat dan Bahan yang digunakan adalah :
1. Laptop
4. Sensor Ultrasonik
7. Relay
10. Pemanas air
2. Mikrokontroler ATMega32
5. Mistar $100 \mathrm{~cm}$
8. Kipas Angin
3. Sensor LM35
6. Termometer
9. Pompa Air

\subsection{Diagram Alir Penelitian}

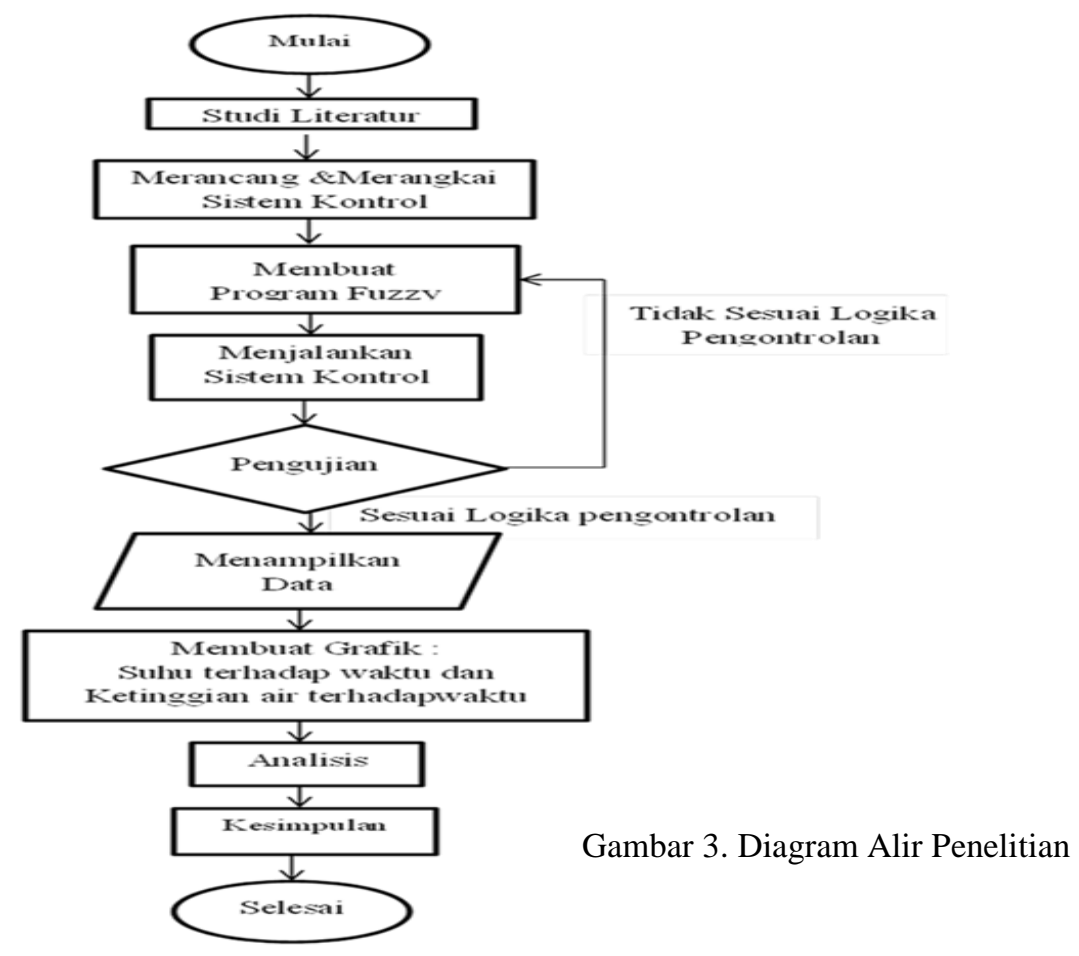




\subsection{Diagram Kerja Alat}

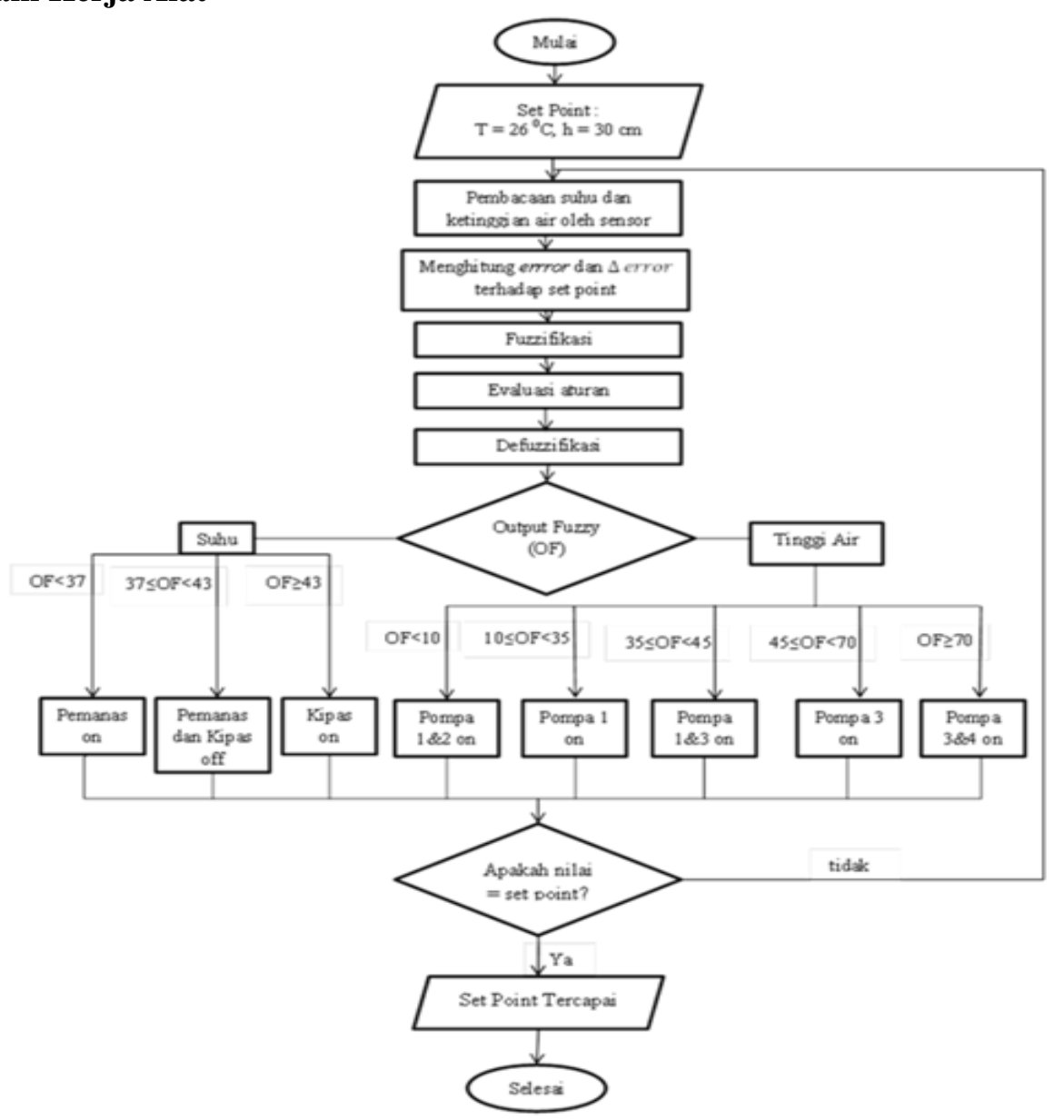

Gambar 4. Diagram Kerja Alat

\subsection{Prosedur Penelitian}

1. Dibuat suatu akuarium yang akan dikontrol suhu dan ketinggian airnya, ukurannya $1.00 \mathrm{~m} \mathrm{x}$ $0.50 \mathrm{~m} \times 0.40 \mathrm{~m}$

2. Sensor suhu LM35 dihubungkan dengan pengkondisi sinyal. Setelah itu output pengkondisi sinyal dihubungkan dengan port A.3 pada sistem minimum mikrokontroler Atmega32.

3. Pin trigger sensor level air HCSR04 dihubungkan dengan port D.1 dan pin echo dihunbungkan dengan port D.6 pada Atmega32

4. Port C.0 sampai port C.7 dihubungkan dengan pin 1 sampai pin 8 pada papan relay.

5. Kipas angin dihubungkan dengan relay pertama sampai relay ketiga. Pemanas pada relay ke-4 dan pompa air pada relay ke-6 sampai ke-7.

6. Sumber daya $12 \mathrm{~V}$ yang berasal dari adaptor dihubungkan dengan papan relay dan sistem minimum mirokontroler Atmega32.

7. Suhu dan ketinggian air yang diinginkan yaitu $26{ }^{\circ} \mathrm{C}$ dan $30 \mathrm{~cm}$ diprogram dengan menggunakan logika fuzzy, kemudian program dimasukkan ke mikrokontroler

8. Termometer dan mistar disiapkan untuk mengukur perubahan suhu dan ketinggian air dalam sistem

9. Sistem kontrol dinyalakan.

10. Temperatur, ketinggian air, dan reaksi sistem dicatat.

11. Setelah semua data dicatat, data diolah dengan menggunakan program microsoft excel untuk mendapatkan tampilan dalam bentuk grafik. 


\section{Hasil dan Pembahasan}

\subsection{Perancangan Sistem Kontrol Suhu dan Tinggi Air}

Pengontrol suhu dan ketinggian air akuarium yang telah dibuat, disusun dalam suatu sistem peralatan seperti pada Gambar 5:

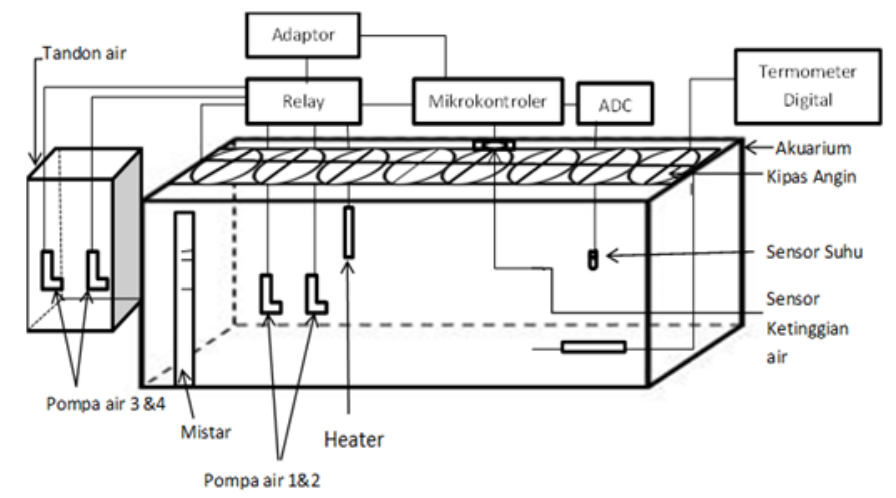

Gambar 5. Rancangan Sistem Pengontrolan Suhu dan Ketinggian air

Setelah keseluruhan komponen dirangkai, keseluruhan sistem kontrol akan tampak seperti Gambar 6:

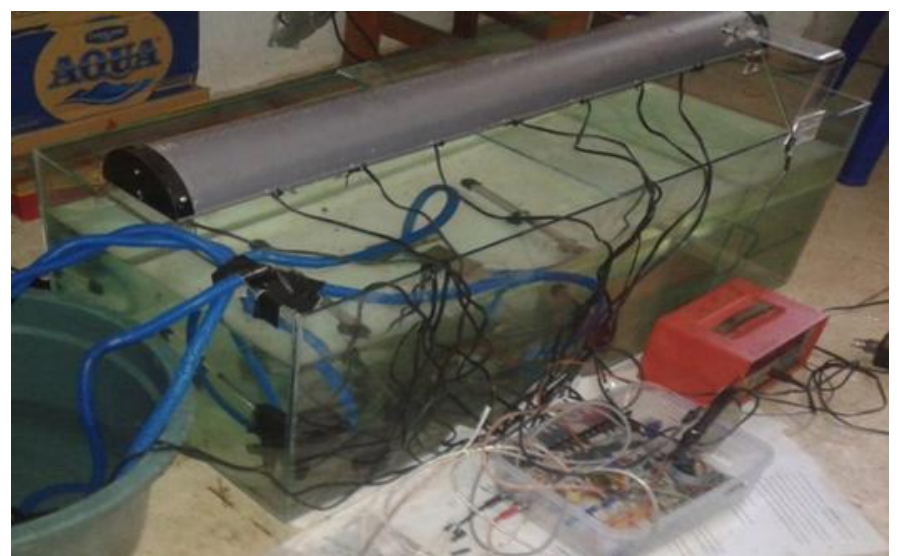

Gambar 6. Sistem Pengontrol Suhu dan Ketinggian Air

Sistem kontrol suhu dan ketinggian air pada Gambar 6 dibuat dengan mengikuti diagram skematik pada Gambar 7 :

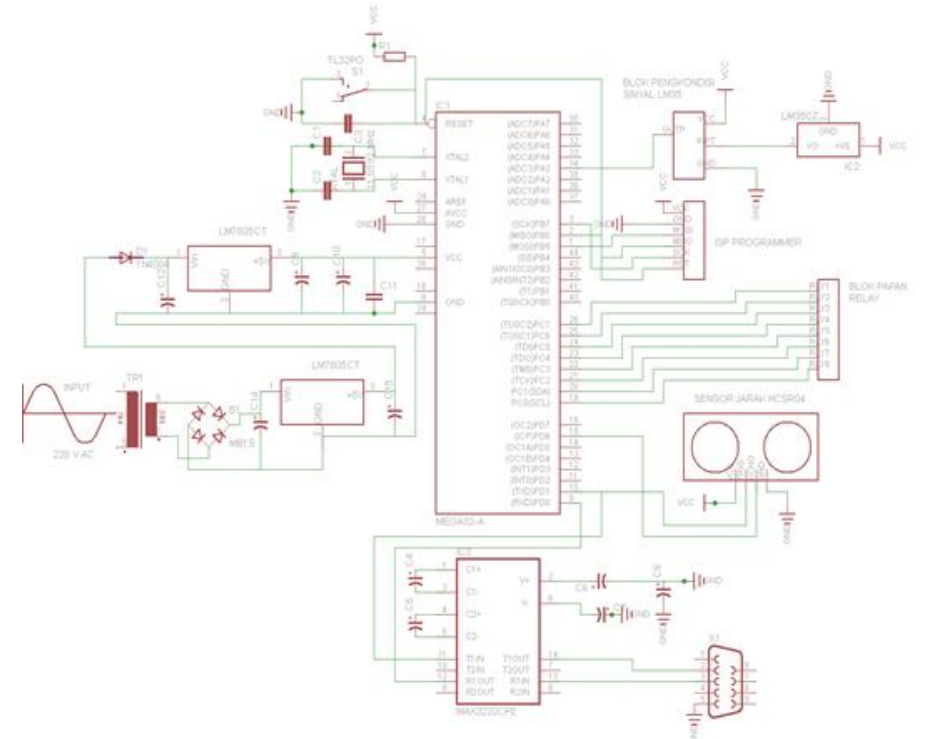

Gambar 7. Diagram Skematik Sistem Kontrol Suhu dan Ketinggian Air 


\subsection{Pembuatan Program Fuzzy}

Program fuzzy dibuat dengan menggunakan dua masukkan yaitu error (e) dan $\Delta$ error (de). Nilai error adalah nilai selisih suhu aktual terhadap suhu set point. $\Delta$ error (de) adalah selisih dari error aktual terhadap error sebelumnya. Fuzzy yang dibuat menggunakan aturan-aturan seperti pada Tabel 1.

Tabel 1. Aturan-aturan fuzzy

\begin{tabular}{|c|c|c|c|c|c|}
\hline $\boldsymbol{d} \boldsymbol{e}$ & SD & D & N & H & P \\
\hline NS & PBk & PBk & N & DSd & DBk \\
\hline S & PBk & PSd & N & DSd & DBk \\
\hline PS & PBK & PSd & N & DBk & DBk \\
\hline
\end{tabular}

Keterangan :

$\begin{array}{llllll}\text { PBk } & \text { : Panaskan Banyak } & \text { DSd } & \text { : Dinginkan Sedang } & \text { N } & \text { : Normal } \\ \text { PSd } & \text { : Panaskan Sedang } & \text { DBk } & \text { : Dinginkan Banyak }\end{array}$

Nilai keluaran fuzzy dihitung dengan menggunakan metode Mamdani min-max dan Centre Of Gravity (COG) bentuk singleton.

\subsection{Pengujian Program Fuzzy}

Untuk membuktikan kebenaran program fuzzy ini, maka nilai keluaran fuzzy pada mikrokontroler akan dibandingkan dengan nilai keluaran fuzzy pada software petrafuzz51. Hasil yang didapatkan memiliki kesesuaian $100 \%$.

\subsection{Uji Pengontrolan Tinggi Air}

Hasil pengontrolan terhadap tinggi air ditampilkan pada Gambar 8 :

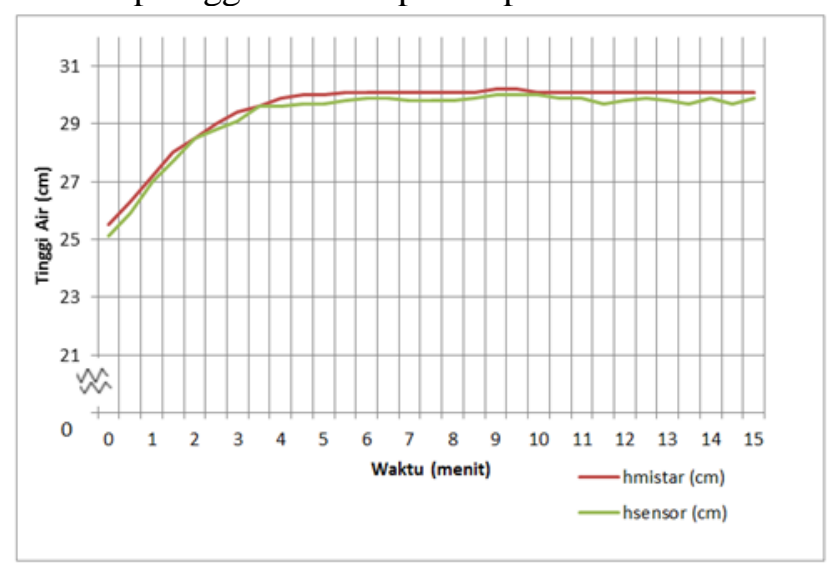

Gambar 8. Grafik Tinggi Air Terhadap Waktu

Berdasarkan Gambar 8, didapatkan bahwa sistem memerlukan waktu 4,5 menit untuk dapat mencapai set point dari ketinggian air semula yaitu $25,5 \mathrm{~cm}$. Berdasarkan hasil pengukuran oleh mistar, tinggi air menjadi stabil pada $30,1 \mathrm{~cm}$, berbeda $0,1 \mathrm{~cm}$ dari set point . Hal ini menujukkan bahwa sistem pengontrolan ketinggian air telah bekerja sesuai dengan kehendak pengontrolan.

Hasil pembacaan ketinggian air oleh sensor jika dibandingkan dengan hasil pembacaan oleh mistar memiliki nilai NRMSE (Normalized Root Mean Square Error) sebesar 0,009. Diperoleh juga bahwa dari pembacaan sensor nilai tinggi air stabil pada $\mathrm{h}=(29,84 \pm 0,02) \mathrm{cm}$, dengan ketelitian 99,93\%. Dengan cara yang sama didapatkan pula dari pembacaan dengan menggunakan mistar bahwa sistem stabil pada $\mathrm{h}=(30,10 \pm 0,01) \mathrm{cm}$ dan ketelitiannya 99,97\%. Dapat dikatakan bahwa sistem pengontrolan ketinggian air telah bekerja dengan baik karena ketinggian air stabil pada daerah yang sangat dekat dengan set point.

\subsection{Uji Pengontrolan Tinggi Air}

Hasil pengontrolan terhadap tinggi air ditampilkan pada Gambar 9. Terlihat bahwa nilai pengukuran suhu oleh sensor dan termometer digital memiliki perbedaan hingga $0,5^{\circ} \mathrm{C}$. 


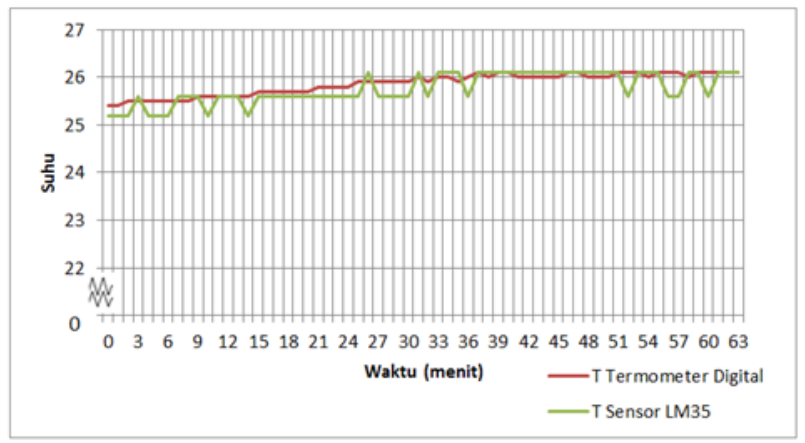

Gambar 9. Grafik Suhu Terhadap Waktu

Hal ini disebabkan oleh kenaikan tegangan sebesar $10 \mathrm{mV} /{ }^{\circ} \mathrm{C}$ yang diterapkan pada ADC (Analog to Digital Converter) 10 bit yang terdapat pada mikrokontroler ATMega 32. Dengan menggunakan ADC 10 bit maka resolusi maksimal yang didapatkan untuk setiap kenaikan 1 bit adalah $5 \mathrm{mV}$. Dengan demikian ketelitian suhu yang bisa didapatkan oleh sensor suhu adalah $0,5^{\circ} \mathrm{C}$.

Hasil pembacaan suhu air oleh sensor jika dibandingkan dengan hasil pembacaan oleh termometer digital memiliki nilai NRMSE (Normalized Root Mean Square Error) sebesar $0,008{ }^{\circ} \mathrm{C}$. Diperoleh juga bahwa dari pembacaan sensor suhu nilai suhu air stabil pada $\mathrm{T}=(26,01 \pm 0,03){ }^{\circ} \mathrm{C}$, dengan ketelitian $99,87 \%$. Dengan cara yang sama didapatkan pula dari pembacaan dengan menggunakan termometer digital bahwa sistem stabil pada $\mathrm{T}=(26,04 \pm 0,01){ }^{\circ} \mathrm{C}$ dan ketelitiannya $99,96 \%$. Dapat dikatakan bahwa sistem pengontrolan ketinggian air telah bekerja dengan baik karena suhu air stabil pada daerah yang sangat dekat dengan set point.

\subsection{Uji Kerja Keseluruhan Sistem}

Pada saat sistem pengontrol dihubungkan dengan sumber tegangan bolak balik $220 \mathrm{~V}$, adaptor mengkonversi tegangannya ke tegangan searah $12 \mathrm{~V}$ untuk menjadi sumber daya untuk operasional mikrokontroler dan relay. Pada saat tinggi air berada di bawah $30 \mathrm{~cm}$ maka pompa inlet ke akuarium akan bekerja, begitu juga sebaliknya. Ketika ketinggian air telah mencapai $30 \mathrm{~cm}$ pompa inlet dan outlet yang berkapasitas sama akan bekerja bersama-sama untuk menjaga aliran air bersih di akuarium. Data hasil pengukuran sensor ultrasonik ditampilkan di laptop untuk kemudian dibandingkan dengan data pengukuran oleh mistar. Hasil pengontrolan untuk tinggi air menunjukkan sistem bekerja dengan sangat baik.

Sistem pengontrolan suhu bekerja sesuai dengan logika pengontrolan ketika suhu air kurang dari $26{ }^{\circ} \mathrm{C}$, pemanas akan memanaskan air dan ketika telah mencapai set point pemanas akan mati. Ketika suhu melebihi set point maka kipas angin akan berjalan untuk mendinginkan. Data hasil pengukuran sensor suhu ditampilkan di laptop untuk kemudian dibandingkan dengan data pengukuran oleh termometer digital. Hasil peng ontrolan untuk suhu air menunjukkan sistem bekerja dengan sangat baik.

\section{Kesimpulan dan Saran}

\subsection{Kesimpulan}

- Program fuzzy untuk pengontrolan suhu dan ketinggian air telah berhasil dibuat dengan menggunakan dua sinyal masukkan yaitu error dan $\Delta$ error.

- Sebuah sistem kontrol suhu dan ketinggian air telah berhasil dirancang dan dibuat dengan menggunakan kontrol logika fuzzy. Dimensi akuarium yang dikontrol suhu dan tinggi airnya memiliki panjang $100 \mathrm{~cm}$, lebar $50 \mathrm{~cm}$ dan tinggi $40 \mathrm{~cm}$. Suhu air berhasil dibuat stabil pada $26,0{ }^{\circ} \mathrm{C}$ dari suhu awal $25,4{ }^{\circ} \mathrm{C}$ dengan nilai NRMSE sebesar 0,008. Waktu yang diperlukan untuk mencapai set point adalah 31 menit. Ketinggian air juga berhasil dibuat stabil pada 29,8 cm dari ketinggian awal air adalah 25,5 cm dengan nilai NRMSE sebesar 0,009. Waktu yang diperlukan untuk mencapai set point adalah 4,5 menit. 


\subsection{Saran}

- Untuk pengontrolan yang lebih baik aktuator suhu dan ketinggian air dapat diganti dengan aktuator yang sesuai dengan kebutuhan.

- Hasil penelitian ini dapat diaplikasikan pada berbagai pengontrolan suhu dan ketinggian air dengan mengatur nilai set point pada program yang telah dilampirkan.

\section{Daftar Pustaka}

[1] Juwana dan M. Unggul. 2006. Sistem Kontrol Proses dan PLC.

[2] Liviawaty, E. 1995. Maskoki Budidaya dan Pemasarannya. Kanisius, Yogyakarta.

[3] Tarigan, P. 2013. Sistem Pengendali Pendingin Ruangan Menggunakan Fuzzy Logic Berbasis Mikrokontroler ATMega 8535. STMIK BUDI DARMA, Medan.

[4] Sunardi J, Sutanto dan Singgih. 2009. Rancang Bangun Antarmuka Mikrokontroler Atmega32 dengan Multimedia Card. Seminar Nasional V, Yogyakarta

[5] Firmansyah, H. 2008. Rancang Bangun Sistem GPS Pada Sepeda Motor Via Atmega32[skripsi]. Universitas Indonesia, Depok.

[6] Nur, M. 2012. Alat Pengukur Suhu Otomatis Berbasis Mikrokontroler ATMega8535 dengan Penampil LCD[skripsi]. Universitas Sumatera Utara, Medan.

[7] Magdalena, G. 2013. Perancangan Sistem Akses Pintu Garasi Otomatis Menggunakan Flatform Android. Prosiding Conference, Bali.

[8] Tumimomor, F. 2009. Perancangan Sistem Pengontrol Suhu Ruang Berbasis Mikrokontroler 89C51[skripsi]. Universitas Sam Ratulangi, Manado.

[9] Gusrina. 2008. Budidaya Ikan Jilid 1. Direktorat Pembinaan Sekolah Menengah Kejuruan, Jakarta.

[10] Bachtiar, Y. 2007. Budidaya Ikan Hias Air Tawar untuk Ekspor. Agromedia Pustaka, Jakarta Selatan. 